\title{
PENGARUH SISTEM INFORMASI MANAJAMEN TERHADAP PENINGKATAN KUALITAS PELAYANAN DI PT. JASARAHARJA PUTRA CABANG BENGKULU
}

Oleh:

\author{
ILHAM AGUSTIAN, HARIUS EKO SAPUTRA, ANTONIO IMANDA \\ Program Studi Administrasi Publik Fakultas Ilmu-Ilmu Sosial \\ Universitas Dehasen Bengkulu
}

\begin{abstract}
This study aims to find the influence of variable X (Management Information System) on variable Y improvement (Service Quality) study at PT. Jasaraharja Putera Bengkulu Branch. This study used a quantitative method with data analysis techniques of Product Moment Correlation analysis. Data collection was done using library techniques, observation, questionnaires (questionnaires), and documentation. The number of samples in this study was 55 respondents. The results of this study indicate that the level of correlation between independent variables $(X)$ the influence of management information systems on variables $(Y)$ improving service quality is in the low category because it is located between 0.20 - 0.399. This proves that the variable $X$ (management information system) with variable $Y$ (service quality) can be declared influential but included in the low category. Management information system $(X)$ has a significant effect on service quality $(Y)$. This can be seen from the results of the t-test calculation of 2,783. While the results of the calculation of determination $r 2=0.128$ or equal to $12.8 \%$ which contains the understanding that the influence of independent variables (management information systems) on the dependent variable increase (service quality) is $12.8 \%$ and can be declared weak, while the remaining $87.2 \%$ is caused by other factors not examined by the researcher.
\end{abstract}

Keywords: management information systems, service quality

\section{PENDAHULUAN}

Pada masa sekarang ini, perkembangan zaman yang semakin global membuat perekonomian sudah banyak bergeser dari perekonomian berbasis industri ke perekonomian berbasis informasi, dengan berkembangnya perekonomian berbasis informasi maka sudah pasti informasi menjadi sesuatu yang sangat penting dikarenakan informasi saat ini merupakan kebutuhan mendasar bagi setiap organisasi. Informasi juga memungkinkan organisasi dapat terus mengantisipasi segala kemungkinan yang terjadi sebagai akibat dari adanya perubahan yang semakin kompleks. Maka dari itu, perusahaan berusaha memberikan dan mendapatkan informasi yang berkualitas karena dengan informasi yang berkualitas tersebut bisa memacu perkembangan organisasinya. Selain itu, penerapan teknologi khususnya sistem informasi akan sangat membantu karyawan dalam melakukan pekerjaannya dengan cara mengurangi keterbatasan yang dimilikinya. Namun sampai sejauh mana pengaruh sistem informasi (terutama berbasis komputer) terhadap kinerja seseorang masih perlu penyelidikan lebih lanjut. Hal ini disebabkan oleh kinerja seseorang yang menggunakan sistem informasi berbasis komputer, dipengaruhi oleh banyak faktor sistem informasi yang secara langsung maupun yang tidak langsung. 
Albrecht dalam Sedarmayanti (2009: 234) ekspektasi kualitas pelayanan pelanggan atau kunci untuk memberikan kualitas pelayanan nasabahsasaran. Kualitas pelayanan yang baik adalah memenuhi atau melebihi digambarkan sebagai suatu pernyataan tentang sikap, hubungan yang dihasilkan dari perbandingan dari ekspektasi dengan kinerja. Jadi tingkat kepuasan merupakan fungsi dari perbedaan antara kinerja yang dirasakan oleh harapan, jika kinerja yang dirasakan dibawah harapan maka konsumen tidak puas, sedangkan jika kinerja yang dirasakan sesuai dengan harapan atau melebihi maka konsumen akan merasa puas. Dan jika kinerja yang dirasakan melampaui harapan maka konsumen akan merasa sangat puas. Salah satu strategi yang dapat menunjang keberhasilan dalam bisnis asuransi adalah berusaha menawarkan kualitas jasa dengan kualitas pelayanan yang tinggi dan nampak dalam performa tinggi dari pelayanan yang ada. Penulis melakukan observasi awal pada lokasi penelitian.

Penggunaan sistem informasi manajemen di PT. Jasaraharja Putera Cabang Bengkulu telah menggunakan sistem informasi berbasis komputer dan menggunakan website, didalam website itu berisi produk, sumber daya manusisa (SDM), keterangan mengenai perusahaan. Dengan adanya website tersebut diharapkan memudahkan nasabah mengakses. Namun dalam hal ini, proses sistem informasi di PT.Jasaraharja Putera Cabang Bengkulu masih bergantung pada jaringan komunikasi dan karyawan masih kurang memahami akan penggunaan sistem informasi manajemen berbasis website itu sendiri. Apalagi di zaman sekarang akses informasi begitu cepat, mudah dan sangat penting. Kebanyakan karyawan terlena dengan cara yang konversional yang berdampak pada kenyamanan, kemudahan nasabah dalam mengakses informasi tentang perusahaan.

Dengan adanya permasalahan diatas, maka dari internal harus melakukan edukasi maupun training kepada karyawan agar lebih dapat memahami akan pentingnya sistem informasi manajem berbasis website. Dalam kaitanya kepuasan nasabah, hal tersebut harus segera dibenahi agar karyawan dapat memberikan pelayanan yang prima kepada nasabah secara lebih profesional. Berdasarkan hal tersebut, maka penulis tertarik untuk melihat bagaimana pengaruh Sistem Informasi Manajemen terhadap Peningkatan Kualitas Pelayanan di PT. Jasaraharja Putera Cabang Bengkulu.

\section{METODE PENELITIAN}

Penelitian ini menggunakan metode kuantitatif. Penelitian kuantitatif dapat diartikan sebagai metode penelitian yang berlandaskan pada filsafat positivismen, digunakan untuk meneliti pada populasi atau sampel tertentu, pengumpulan data menggunakan instrument penelitian, analisis data bersifat kuantitatif atau statistik, dengan tujuan untuk menguji hipotesis yang telah ditetapkan. Sugiyono (2015:23) Penelitian ini dilakukan dengan metode survei, dimana metode penelitian survei adalah metode penelitian kuantitatif yang digunakan untuk mendapatkan data yang terjadi pada masa lampau atau saat ini, tentang keyakinan, pendapat, karakteristik, perilaku, hubungan variable dan untuk menguji beberapa hipotesis tentang variable sosiologis dan psikologis dari sampel yang diambil dari populasi tertentu, teknik pengumpulan data dengan pengamatan (wawancara atau kuisioner) dan hasil penelitian cenderung untuk digeneralisasikan. Sugiyono (2005:24).

Menurut Sugiyono (2016:39) menjelaskan mengenai pengertian dari variabel yaitu: "Variabel penelitian adalah suatu atribut atau sifat atau nilai dari orang, atau obyek atau kegiatan yang mempunyai variasi tertentu yang ditetapkan oleh peneliti untuk dipelajari dan kemudian ditarik kesimpulannya". Dalam penelitian ini penulis melakukan pengukuran terhadap keberadaan suatu 
variabel dengan menggunakan instrumen penelitian. Setelah itu penulis akan melanjutkan analisis untuk mencari hubungan suatu variabel dengan variable lain. Menurut Sugiono (2016: 39) berdasarkan hubungan antara suatu variabel dengan variabel lain, maka variabel dalam penelitian ini adalah sebagai berikut:

Variabel Bebas (Independent
Variable)
Variabel bebas adalah variabel yang mempengaruhi atau yang menjadi sebab perubahannya atau timbulnya variabel terikat. Maka dalam penelitian ini yang menjadi variabel bebas (Independent Variable) adalah Sistem Informasi Manajemen (X).

2) Variabel Terikat (Dependent Variable)

Variabel terikat adalah variabel yang dipengaruhi atau yang menjadi akibat adanya variabel bebas. Maka dalam penelitian ini yang menjadi variabel terikat (Dependent Variable) adalah Kualitas pelayanan (Y).

\section{Operasional Variabel}

Definisi Operasional, menurut Saifudin Azwar (2007:72) adalah suatu definisi yang memiliki arti tunggal dan diterima secara objektif bilamana indikatornya tidak tampak. Suatu definisi mengenai variabel yang dirumuskan berdasarkan karakteristik-karakteristik variabel yang diamati. Agar tidak terjadi kesalahpahaman dalam memaknai judul skripsi ini, maka perlu dijelaskan tentang definisi operasional dari judul tersebut sebagai berikut. (Tabel 3.1 s.d 3.2 terlampir).

\section{Populasi Dan Sampel}

Dalam penelitian ini, populasi penelitian mengacu pada pengguna atau nasabah yang masih aktif menggunakan asuransi bermotor di PT. Jasa Raharja
Putera Cabang Bengkulu yang berjumlah 300 orang. Untuk menentukan jumlah sampel dapat menggunakan rumus Isaac dan Michael berdasarkan tingkat kesalahan $1 \%$, 5\%, dan 10\%, Sugiyono (2015:67).

\section{Teknik Pengumpulan Data}

Data adalah unit informasi yang direkam media yang dapat dibedakan dengan data lain, dapat dianalisis dan relevan dengan program tertentu. Pengumpulan data adalah prosedur yang sitematik dan standar untuk memperoleh data yang diperlukan. Pada penelitian ini, penulis menggunakan dua metode pengumpulan data, yaitu:

1. Penelitian Kepustakaan (Library research), yaitu teknik pengumpulan data dengan berdasarkan literaturliteratur yang berhubungan dengan objek penelitian sebagai landasan teoritis. Bahan dan teori ini bersumber dari buku ilmiah, bahan kuliah, diklat, maupun artikel-artikel yang berhubungan dengan judul penelitian ini.

2. Penelitian Lapangan (Field Research), yaitu teknik pengumpulan data yang dilakukan secara langsung ke objek penelitian yaitu dengan:

a. Observasi Menurut Sutrisno Hadi dalam Sugiyono (2016:145), mengemukakan bahwa, observasi merupakan suatu proses yang kompleks, suatu proses yang tersusun dari proses biologis dan psikologis. Dua diantara yang terpenting adalah proses pengamatan dan ingatan.

b. Kuisioner (Angket) Kuisioner merupakan teknik pengumpulan data yang dilakukan dengan cara memberi separangkat pertanyaan atau pernyataan tertulis kepada responden untuk dijawabnya. Kuisioner merupakan teknik pengumpulan datan yang efisien bila peneliti tahu dengan pasti variabel yang akan diukur dan 
tahun apa yang diharapkan dari responden, Sugiyono (2016:142)

c. Dokumentasi Menurut Sugiyono (2010:240), dokumentasi merupakan catatan peristiwa yang sudah berlalu yang dapat berupa tulisan, gambar, atau karya-karya monumental dari seseorang. Teknik dokumentasi dalam penelitian digunakan untuk memperoleh data atau informasi tertulis atau suatu hal tertentu yang diambil dari suatu lembaga maupun secara mandiri melalui pendataan atau pengambilan gambar dilokasi penelitian. Pengumpulan data dalam penelitian ini menggunakan metode survei.

Dalam penelitian survei, teknik pengumpulan data yang banyak digunakan adalah dengan test, questioner, wawancara dan observasi tertutup .Sugiyono (2015:71). Sebagai alat pengukur variabel pada kuisioner digunakan Skala Likert. Dengan skala Likert, maka variabel yang akan diukur dijabarkan menjadi indikator variabel. Kemudian indikator tersebut dijadikan sebagai titik tolak untuk menyusun item-item instrumen yang dapat berupa pernyataan atau pertanyaan. Skoring yaitu proses pemberian nilai atau harga, berupa angka-angka pada jawaban untuk memperoleh data kuantitatif yang diperlukan dalam pengujian hipotesis. (Tabel 3.3 terlampir).

\section{Teknik Analisa Data}

Dalam penelitian ini juga, teknik analisis yang digunakan adalah teknik analisis deskriptif yang dilakukan dengan cara statistik deskriptif yakni mendeskripsikan atau menggambarkan data yang telah terkumpul dengan membuat generalisasi hasil penilitian. Dalam metode penelitian ini penyajian data dapat berupa tabel, grafik, diagram, persentase dan frekuensi. Tujuan dari analisis data ini adalah; Pertama, untuk mendeskripsikan data dalam bentuk feekuensi maupun tabel sebagai karakteristik datanya mudah dipahami. Kedua, untuk menarik kesimpulan tentang masalah yang sedang diteliti. Dalam penelitian ini pengujian hipotesis yang digunakan adalah pengujian hipotesis asosiatif, yakni dugaan adanya hubungan/pengaruh dalam populasi melalui data hubungan variabel dalam sampel. Data penelitian yang terkumpul akan dianalisis melalui pendekatan kuantitatif dengan menggunakan teknik atau uji sebagai berikut:

\section{Uji Validitas}

Menurut Arikunto (2010:267) validitas adalah Derajat ketetapan antara data yang terjadi pada objek penelitian dengan daya yang dapat dilaporkan oleh penelitian. Dengan demikian data yang valid adalah data "yang tidak berbeda" antara data yang dilaporkan oleh peniliti dengan data yang sesungguhnya terjadi pada objek penelitian. Instrumen yang digunakan dalam penilitian perlu diuji validitas dan reliabilitas. Uji validitas menyatakan bahwa instrumen yang digunakan untuk mendapatkan data dalam penelitian dapat digunakan atau tidak. Sedangkan uji reliabilitas menyatakan bahwa apabila instrumen yang apabila digunakan beberapa kali untuk mengukur objek yang sama akan menghasilkan data yang sama. Uji validitas instrumen dalam penelitian ini menggunakan content validity yang dapat menggambarkan kesesuaian sebuah pengukur data dengan apa yang diukur dengan menggunakan program SPSS versi 20. Adapun kriteria penilaian uji validitas sebagai berikut:

a. Apabila $r_{\text {hitung }}>r_{\text {tabel }}$, maka dapat dikatakan kuesioner tersebut valid

b. Apabila $r_{\text {hitung }}<r_{\text {tabel }}$, maka dapat dikatakan kuesioner tidak valid.

\section{Uji Reliabilitas}

Uji reliabilitas menurut Sugiyono 
(2010:3354) dilakukan untuk mengetahui seberapa jauh hasil pengukuran tetap konsisten apabila dilakukan pengukuran dua kali atau lebih terhadap gejala yang sama dengan menggunakan alat pengukur sama. Uji reliabilitas dilakukan untuk mengetahui apakah alat ukur yang dirancang dalam bentuk kuesioner dapat diandalakn, suatu alat ukur dapat diandalakan jika alat ukur tersebut digunakan berulangkali akan memberikan hasil yang relatif sama (tidak berbeda jauh). Untuk melihat andal tidaknya suatu alat ukur digunakan pendekatan secara statistika, yaitu melalui koesfien reliabilitas dan apabila koefisien relibilitasnya lebih besar (>) dari 0,60 maka secara kesuluruhan pernyataan tersebut andal (reliabel). (Tabel 3.4 terlampir).

\section{Uji Kolerasi Product Moment}

Untuk mengetahui ada atau tidaknya Pengaruh Sistem Informasi Manajemen Terhadap Peningkatan Kualitas Pelayanan pada PT. Jasaraharja Putera Cabang Bengkulu akan dianalisa melalui uji Korelasi product Moment dengan rumus sebagai berikut :

$$
\text { r. } X Y=\frac{\text { n. }(\Sigma X Y)(\Sigma X)(\Sigma Y)}{\sqrt{ }[][]}
$$

$\mathrm{r}=$ Koefisien kolerasi Variabel $\mathrm{X}$ dan $\mathrm{Y}$

$\mathrm{X}=$ Variabel Sistem informasi Manajemen

$\mathrm{Y}=$ Variabel Kualitas Pelayanan

$\mathrm{N}=$ Jumlah Responden

$\sum=$ Jumlah/total

Selanjutnya untuk mengetahui hubungan antara dua variabel dan untuk mengetahui arah hubungan yang terjadi menggunakan analisis kolerasi sederhana (Bivariate Correlation). Koefisien kolerasi sederhana menunjukkan seberapa besar hubungan yang terjadi antara dua variabel, yaitu variabel sistem informasi manajemen dengan kualitas pelayanan. (Tabel 3.5 terlampir).

\section{Uji Hipotesis}

Nilai $t$ digunakan untuk menguji pengaruh dari masing-masing variabel independen terhadap variabel dependen juga dilakukan dengan melihat nilai probabilitasnya (signifikansi), dimana apabila nilai signifikan $\mathrm{t}<0,05$, maka itu artinya variabel independen berpengaruh terhadap dependen, sebaliknya apabila nilai signifikan $\mathrm{t}>0,05$ itu berarti variabel independen tidak berpengaruh terhadap variabel dependen. Selanjutnya, untuk melihat arah pengaruh maka dilihat dari koefisien regresi. Apabila koefisien regresi positif berarti pengaruh positif dan apabila koefisien regresi negatif berarti pengaruh negatif. Untuk membuktikan apakah setiap variabel bebas $(\mathrm{X})$ mempunyai pengaruh yang signifikan terhadap variabel terikat (Y) secara parsial. Kriteria pengujian adalah sebagai berikut:

$\mathrm{H}_{1}$ diterima dan $\mathrm{H}_{0}$ ditolak, artinya terdapat pengaruh sistem informasi manajemen terhadap kualitas pelayanan.

$\mathrm{H}_{1}$ ditolak $\mathrm{H}_{0}$ diterima, artinya tidak terdapat pengaruh sistem informasi manajemen kualitas pelayan.

Jika $\mathrm{r}_{\text {hitung }} \geq \mathrm{r}_{\text {tabel }}$ maka $\mathrm{H}_{\mathrm{o}}$ ditolak dan $\mathrm{H}_{\mathrm{a}}$ diterima Jika $\mathrm{r}_{\text {hitung }} \leq$ $\mathrm{r}_{\text {tabel }}$ maka $\mathrm{H}_{\mathrm{o}}$ diterima dan $\mathrm{H}_{\mathrm{a}}$ ditolak Ket:

$\mathrm{H}_{\mathrm{o}}: p=0$ (tidak ada pengaruh /hubungan) $\mathrm{H}_{\mathrm{a}}: p \neq 0$ (ada pengaruh / hubungan)

\section{Koefisien Determinasi $\left(\mathbf{r}^{2}\right)$}

Analisis koefisien determinasi dilakukan untuk mengetahui seberapa besar pengaruh variabel independen (X) terhadap variabel dependen (Y). Semakin besar nilai determinasi semakin besar kemampuan variabel independen menerangkan variabel dependen. Hal ini berarti model yang digunakan semakin 
kuat untuk menerangkan pengaruh variabel bebas yang diteliti terhadap variabel terikat. Sebaliknya jika determinasi r2 semakin kecil (semakin mendekat) maka dapat dikatakan bahwa pengaruh variabel independen terhadap variabel dependen semakin kecil.

Rumus untuk koefisien determinasi $\left(\mathrm{r}^{2}\right): \mathrm{KD} \quad=\mathrm{r}^{2} \times 100 \%$

Keterangan:

$\mathrm{KD}=$ Koefisien determinasi $\mathrm{r}^{2}=$ Koefisien korelasi Variabel $\mathrm{X}$ dan $\mathrm{Y}$

\section{HASIL PENELITIAN DAN PEMBAHASAN}

Penelitian ini mengenai "Pengaruh Sistem Informasi Manajemen Terhadap Peningkatan Kualitas Pelayanan pada PT.Jasaraharja Putera Cabang Bengkulu" dapat dibuat dalam pembahasan.

Berdasarkan hasil pengolahan data kuesioner, maka dapat diperoleh identitas ataupun karakteristik responden didominasi oleh responden yang berjenis kelamin laki-laki yang ditunjukkan pada tabel 5.1 (terlampir). Usia responden terbanyak yaitu > 40 tahun yang ditunjukkan pada tabel 5.2 (terlampir). Pada tabel 5.3 (terlampir) menunjukkan karakteristik responden berdasarkan pendidikan terakhir yang mana didominasi oleh tamatan S1 (sarjana) berjumlah 33 orang. Dari karakteristik responden berdasarkan pekerjaan didominasi oleh pegawai swasta yang mana ditunjukkan pada tabel 5.4 (terlampir). Sedangkan pada tabel 5.5 (terlampir) menunjukkan karakteristik responden dengan lama menjadi nasabah >1-5 tahun berjumlah 31 orang dapat dipersentase kan sebesar $56,36 \%$. Penelitian ini menggunakan dua variabel yaitu variabel sistem informasi manajemen (X) dan variabel kualitas pelayanan $(\mathrm{Y})$.

Penelitian pada variabel sistem informasi manajemen yang berbasis komputer ini menunjukkan hasil yang baik. Hal ini dapat dilihat jawaban positif responden yang dibagi menjadi 5 indikator yaitu manusia, perangkat keras (hardware), perangkat lunak (software), data, dan jaringan. Berdasarkan ke-5 indikator tersebut kemudian dikembangkan menjadi 15 pernyataan mengenai sistem informasi manajemen yang diterapkan dalam perusahaan. Berdasarkan penelitian yang dilakukan dari hasil jawaban responden melalui kuesioner yang disebar kepada 55 responden, respon positif tertinggi dengan kategori setuju (sangat setuju dan setuju) terdapat pada indikator kelima dengan butir pernyataan tentang pemanfaatan teknologi informasi memudahkan pegawai dalam memberikan infromasi yang tersedia, terdapat 18 orang responden yang menjawab kategori sangat setuju dengan persentase sebesar $32,7 \%$ dan terdapat 36 orang responden menjawab kategori setuju dengan jumlah persentase sebesar $65,5 \%$. Oleh karena itu, pada butir pernyataan ini memperoleh persentase tertinggi dari jawaban responden yang menyatakan setuju dibandingkan dengan pernyataan lainnya yaitu sebesar $98,2 \%$ yang dapat dilihat pada tabel 5.20 (terlampir). Hal ini menunjukkan bahwa tanggapan responden mengenai pemanfaatan teknologi informasi memudahkan pegawai dalam memberikan infromasi yang tersedia dapat dinyatakan sangat setuju.

Sebaliknya, jumlah jawaban responden terendah dengan persentase sebesar $70,9 \%$ terdapat pada indikator kedua dengan butir pernyataan setiap pekerjaan atau tugas membutuhkan teknologi komputer terdapat pada tabel 5.11 (terlampir). Hal ini disebabkan oleh jawaban responden yang terdapat 14 orang responden menjawab kategori sangat setuju dengan persentase sebesar $25,45 \%$ dan terdapat 25 orang responden menjawab kategori setuju dengan persentase $45,45 \%$, terdapat 9 orang responden menjawab ragu-ragu dengan persentase sebesar $16,4 \%$ dan terdapat 7 
orang responden menjawab kurang setuju, sedangkan kategori terendah pada kategori sangat tidak setuju dengan persentase $0 \%$. Data diatas menunjukkan tanggapan responden bahwa setiap pekerjaan atau tugas selalu membutuhkan teknologi komputer dapat dinyatakan setuju adapun ada 7 orang responden menjawab kurang setuju atau setiap pekerjaan tidak selalu menggunakan media komputer, akan tetapi dengan pekerjaan yang dilakukan dengan menggunakan teknologi komputer akan dapat membantu dalam pelaksanaan pelayanan.

Selanjutnya pada variabel kualitas pelayanan perhitungan yang dilakukan dari hasil jawaban responden melalui kuesioner yang disebar kepada 55 orang responden, respon positif atau tertinggi dengan kategori setuju (sangat setuju dan setuju) terdapat pada indikator kelima dengan butir pernyataan ketelitian karyawan saat melayani nasabah terlihat baik dimana terdapat terdapat 20 orang responden yang menjawab kategori sangat setuju dengan persentase $36,4 \%$ dan 35 orang responden yang menjawab kategori setuju dengan persentase 63,6\%, sedangkan skor terendah pada kategori ragu-ragu, kurang setuju dan sangat tidak setuju dengan persentase $0 \%$.

Oleh karena itu, pada butir pernyataan ini memperoleh persentase tertinggi dari jawaban responden yang menyatakan setuju dibandingkan dengan pernyataan lainnya yaitu sebesar $100 \%$ yang dapat dilihat pada tabel 5.40 (terlampir). Berdasarkan persentase diatas dapat menunjukkan bahwa tanggapan responden mengenai ketelitian karyawan saat melayani nasabah terlihat sudah baik dapat dinyatakan dengan setuju. Sebaliknya, jumlah jawaban responden terendah dengan jumlah persentase sebesar $72,7 \%$ terdapat pada indikator ketiga dengan butir pernyataan tentang kemudahan dihubungi telepon terlihat sudah baik, terdapat 14 orang responden yang menjawab kategori ragu-ragu dengan persentase $25,5 \%$ dan 29 orang menjawab kategori setuju dengan persentase 52,7\%, 14 orang responden menjawab ragu-ragu dengan persentase $25,5 \%$, sedangkan skor terendah pada kategori sangat tidak setuju dengan persentase $0 \%$. Hal ini menunjukkan bahwa tanggapan responden mengenai kemudahan dihubungi melalui telepon terlihat sudah baik dapat dinyatakan dengan setuju meski masih ada responden menjawab ragu-ragu dengan jumlah 14 orang terdapat pada tabel 5.33 (terlampir).

Hasil uji validitas pada variabel sistem informasi manajemen (X), seluruh butir pernyataan dinyatakan valid. Hal ini dapat dilihat dari tabel validitas dengan $\mathrm{r}_{\text {hitung }}>\mathrm{r}_{\text {tabel }}$ dimana nilai $\mathrm{r}$ tabel sebesar 0,266 terdapat pada tabel 5.42 (terlampir). Pada data variabel kualitas pelayanan (Y) yang valid yaitu item y1, y2, y3, y4, y5, y6, y8, y9, y10, y11, y12, y13, y14, y15, $\mathrm{y} 16, \mathrm{y} 17, \mathrm{y} 18, \mathrm{y} 19, \mathrm{y} 20, \mathrm{y} 21$, dan y22 sedangkan item yang tidak valid akan dibuang. Dari hasil pengujian tersebut bisa dilihat bahwa nilai semua menyatakan rhitung $(0,266)>r_{\text {tabel }}$, dan dapat disimpulkan bahwa semua pernyataan kualitas pelayanan variabel (Y) adalah valid dan terdapat pada tabel 5.43 (terlampir). Hasil uji reliabilitas untuk variabel sistem informasi manajemen dengan nilai cronbach's alpha sebesar 0,769 , sehingga dapat disimpulkan bahwa nilai $\mathrm{r}$ alpha positif dan lebih besar $\mathrm{r}$ tabel $(0,769>0,6)$ terdapat pada tabel 5.44 (terlampir), maka instrumen yang digunakan dalam penelitian ini merupakan instrumen yang reliabel. Pada variabe kualitas pelayanan dengan nilai cronbach's alpha sebesar 0,859, sehingga dapat disimpulkan bahwa nilai $\mathrm{r}$ alpha positif lebih atau besar dari $r_{\text {tabell }}(0,859)>$ 0,6 ), maka instrumen yang digunakan dalam penelitian dalam kualitas pelayanan variabel (Y) dinyatakan reliabel dan terdapat pada tabel 5.45 (terlampir).

Berdasarkan uji korelasi product moment dapat diketahui bahwa hasil $r_{x y}$ adalah 0,357. Nilai ini lebih besar dari $r$ tabel harga kritik produt moment dengan 
$\mathrm{N}=55$ dengan nilai taraf signifikan $5 \%$ sebesar 0,266 yaitu $r_{x y}>r_{\text {tabel }}$ atau 0,357 > 0,266 . Sehingga hal ini menunjukkan ada hubungan korelasi antara variabel $\mathrm{x}$ dan $\mathrm{y}$. Berdasarkan pedoman koefisien korelasi, maka koefisien yang dtemukan sebesar 0,357 termasuk pada kategori rendah karena berada direntang $0,20-0,399$ terdapat pada tabel 5.47 (terlampir). Hasil dari uji korelasi product moment dikonsultasikan dengan $r_{\text {tabel. }}$ Setelah diadakan uji korelasi product moment, maka hasil uji korelasi product moment diketahui bahwa $\mathrm{r}_{\mathrm{xy}}=0,357$ berarti siginfikan artinya hipotesis diterima, karena $r_{x y}=0,357>r_{\text {tabel }}(0,266)$ pada taraf signifikansi $5 \%$ terdapat pada tabel 5.48 (terlampir).

Selanjutnya uji regresi linear sederhana terdapat pada tabel 5.49 (terlampir). Nilai konstan $(\alpha)$ dari Unstandardized Coefficients sebesar 55,484 menunjukkan bahwa jika variabel bebas(Sistem Informasi Manajemen) berinilai 0,000 maka berbanding lurus atau nilai konsistensi variabel terikat (kualitas pelayanan) adalah sebesar 55,484 atau mengandung arti bahwa nilai konsisten variabel kualitas pelayanan sebesar 55,484. Nilai koefisien X(b) sebesar 0,493 menunjukkan bahwa variabel sistem informasi manajemen berpengaruh positif terhadap kualitas pelayanan, atau dengan kata lain jikat ditingkatkan nilai sistem informasi manajemen sebesar 1\% maka akan meningkatkan kualitas pelayanan sebesar 0,493 atau dapat dijelaskan dengan koefisien regresi X sebesar 0,493 menyatakan bahwa setiap penambahan $1 \%$ nilai Sistem Informasi Manajemen, maka nilai kualitas pelayanan bertambah besar 0,493. Koefisien regresi tersebut bernilai positif, sehingga dapat dikatakan bahwa arah pengaruh variabel $\mathrm{X}$ terhadap $\mathrm{Y}$ adalah positif.

Pengujian hipotesis dilakukan dengan uji t untuk menguji secara parsial apakah variabe bebas yang terdiri dari variabel sistem informasi manajemen (X) mempunyai pengaruh yang signifikan terhadap variabel kualitas pelayanan (Y). Pada tabel 5.50 (terlampir), dapat dilihat bahwa terdapat pengaruh antara variabel sistem informasi manajemen (X) terhadap kualitas pelayanan (Y). Hipotesis diterima apabila nilai $t_{\text {hitung }}>t_{\text {tabel }}$. Nilai $t_{\text {hitung }}$ dapat dilihat pada tabel yaitu sebesar 2,783 sedangkan untuk nilai tabel dapat dilihat pada tabel statistik pada signifikansi 0,05 yaitu sebesar 1,673. Maka dapat disimpulkan nilai $t_{\text {hitung }}>\mathrm{t}_{\text {tabel }}(2,783>$ 1,673) maka hipotesis diterima. Jadi dapat disimpulkan bahwa sistem informasi manajemen baik maka kualitas pelayanan juga akan baik. Berdasarkan signifikansi $0,000<0,05$ dinyatakan hipotesis nol (Ho) ditolak dan hipotesi (H1) diterima.

Berdasarkan hasil perhitungan koefisien determinasi $\left(\mathrm{r}^{2}\right)$ bahwa besarnya yang dapat dilihat pada tabel 5.51 (terlampir) dengan nilai korelasi atau hubungan (R) yaitu sebesar 0,357. Dari ouput tersebut diperoleh koefisien determinasi (R Square) sebesar 0,128 atau sebesar $12,8 \%$ yang mengandung pengertian bahwa pengaruh variabel bebas (Sistem Informasi Manajemen) terhadap variabel terikat peningkatan (kualitas pelayanan) adalah $12,8 \%$ dan bisa dinyatakan lemah, sedangkan sisanya $87,2 \%$ disebabkan oleh faktor- faktor lainnya atau tidak terdapat dan juga tidak dapat dijelaskan dalam penelitian ini.

\section{PENUTUP \\ Kesimpulan}

Berdasarkan hasil penelitian dan pengolahan data yang telah penulis lakukan, maka penulis dapat menarik kesimpulan mengenai judul "Pengaruh Sistem Informasin Manajemen Terhadap Peningkatan Kualitas Pelayanan pada PT.Jasaraharja Putera Cabang Bengkulu" yaitu sebagai berikut:

1. Dari hasil penelitian terbukti bahwa tingkat korelasi antar variabel bebas (X) Pengaruh Sistem Informasi Manajemen dengan variabel terikat (Y) Peningkatan Kualitas Pelayanan 
berada pada kategori rendah karena berada direntang $0,20-0,399$. Dengan demikian variabel X (Sistem Informasi Manajemen) dengan variabel Y (Kualitas Pelayanan) dapat dinyatakan berpengaruh namun termasuk pada kategori rendah.

2. Dari hasil uji $t$ pada penelitian ini menunjukkan nilai $t_{\text {hitung }}>\mathrm{t}_{\text {tabel }}(2,783$ $>2,004)$ yang berarti maka hipotesis diterima. Jadi dapat disimpulkan bahwa sistem informasi manajemen berpengaruh signifikan terhadap kualitas pelayanan. Nilai thitung positif berarti pengaruhnya positif, yaitu jika sistem informasi manajemen baik maka tingkat kualitas pelayanan juga akan baik.

3. Dari hasil uji koefisien determinasi diketahui nilai $\mathrm{R}$ Square sebesar 0,128 atau sebesar $12,8 \%$ yang mengandung pengertian bahwa pengaruh variabel bebas (Sistem Informasi Manajemen) terhadap variabel terikat peningkatan (kualitas pelayanan) adalah $12,8 \%$ dan dapat dinyatakan lemah, sedangkan sisanya $87,2 \%$ disebabkan oleh faktor-faktor atau variabel lainnya.

\section{Saran}

Berdasarkan hasil penelitian, pengujian, pembahasan dan keterbatasan yang telah penulis sajikan, maka penulis mencoba memberikan saran untuk diperhatikan oleh peneliti selanjutnya dan pihak-pihak yang berada di PT.Jasaraharja Putera Cabang Bengkulu yaitu sebagai berikut:

1. Pada penelitian ini, sistem informasi manajemen secara signifikan mempengaruhi kualitas pelayanan. Oleh karena itu, pihak perusahaan perlu memperhatikan dan memantau kinerja pegawai agar lebih memahami akan pentingnya penggunaan komputer dalam pelaksanaan pelayanan agar mencapai tujuan atau target yang telah ditetapkan sesuai program kerja yang telah direncanakan. Selain itu, dengan adanya sistem informasi yang baik akan mampu meningkatkan kualitas pelayanan terhadap masyarakat sesuai visi perusahaan itu sendiri.

2. Guna meningkatkan kinerja pegawai,diharapkan pihak sub divisi SDM PT.Jasaraharja Putera Cabang Bengkulu harus memberikan diklat (pendidikan dan latihan) kepada pegawai ataupun karyawan yang menunjang kemajuan kinerja karyawan yang berujung kepada kualitas pelayanan yang lebih baik.

3. Pada saat rekruitmen pegawai hendaknya pihak perusahaan melakukan uji kompetensi di bidang teknologi informasi agar dapat menciptakan pegawai ataupun karyawan yang mumpuni dalam melaksanakan pelayanan sistem informasi manajemen terkhusus pada basis komputer.

4. Dengan penelitian ini diharapkan dapat membantu mahasiswa/i, dosen dan para peneliti dapat memanfaatkan skripsi ini yang berhubungan dengan sistem infromasi manajemen, walaupun demikian penelitian ini tiak luput dari berbagai kekurangan.

DAFTAR PUSTAKA

Taufiq, Rohmat. 2013. Sistem Informasi Manajemen. Yogyakarta , Graha Ilmu.

Hardiyansyah. 2011. Kualitas Pelayanan Publik. Yogyakarta : Gava Media Sedarmayanti. 2009. Reformasi Administrasi Publik, Reformasi Birokrasi, Dan Kepemimpinan Masa Depan. Bandung, PT Refika Aditama

Sugiyono. 2015. Cara Mudah Menyusun : Skripsi, Tesis, dan Disertasi. Bandung, Alfabeta. 
Sugiyono. 2016. Metode Penelitian

Kuantitatif, Kualitatif, dan $R \& D$. Bandung, Alfabeta.

Bali Pamungkas, Ibrahim. 2017. Pengaruh Sistem Informasi Manajemen, Kompetensi, Motivasi Terhadap Kinerja Karyawan Pada PT. Circleka Indonesia Utama (Wilayah Jakarta). Jurnal Fak. Ekonomi Universitas Pamulang.

Fajrin, Johan. 2009. Pengaruh Sistem Informasi Manajemen (SIM) Berbasis Komputer Terhadap Kinerja Karaywan pada PT Golden Gate Mandiri. Jurnal Fak. Bisnis dan Manajemen Universitas Widyatama.
Sutabri, Tata. 2017. Sistem Informasi Manajemen edisi revisi. Yogyakarta, Andi

Naidah. 2009. Pengaruh Sistem Informasi Manajemen Terhadap Kinerja Karyawan Pada PT. Metro Batavia Air Distrik Makassar. Jurnal Fak. Ekonomi dan Bisnis Universitas Muhammadiyah Makassar.

Legi Maulana, Sri Suwarsi, dan Abdurrahaman Dudung. 2016. Pengaruh Sistem Informasi Manajemen (Simpeg) dan Lingkungan Kerja terhadap Kinerja Karyawan Pada PT.PLN (Persero) Bandung Distribusi Jawa Barat dan Banten. Jurnal Prosiding Manajemen Fak. Ekonomi dan Bisnis Universitas Islam Bandung. 


\section{LAMPIRAN TABEL}

Tabel 3.1

Intsrumen Pengukuran Variabel X (Sistem Informasi Manajemen)

\begin{tabular}{|c|c|c|}
\hline Variabel & Indikator & Ukuran \\
\hline \multirow{18}{*}{$\begin{array}{l}\text { Sistem Informasi } \\
\text { Manajemen (X) } \\
\text { adalah kumpulan } \\
\text { dari sub-sub } \\
\text { system yang } \\
\text { saling } \\
\text { terintegrasi dan } \\
\text { berkolaborasi } \\
\text { untuk membantu } \\
\text { manajemen } \\
\text { dalam } \\
\text { menyelesaikan } \\
\text { masalah dan } \\
\text { memberikan } \\
\text { informasi yang } \\
\text { berkualitas } \\
\text { kepada } \\
\text { manajemen } \\
\text { dengan cara } \\
\text { mengolah data } \\
\text { dengan komputer } \\
\text { sehingga bernilai } \\
\text { tambah dan } \\
\text { bermanfaat bagi } \\
\text { pengguna.Rohma } \\
\text { t taufiq (2013:58) }\end{array}$} & \multirow[t]{6}{*}{ 1. Manusia } & 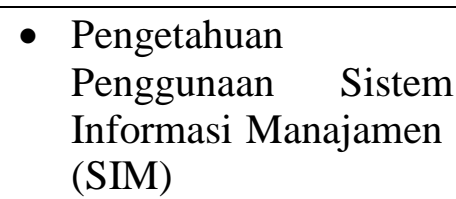 \\
\hline & & $\begin{array}{l}\text { - Kemampuan } \\
\text { Penggunaan }\end{array}$ \\
\hline & & $\begin{array}{l}\text { Informasi Manajamen } \\
\text { - (SIM) }\end{array}$ \\
\hline & & 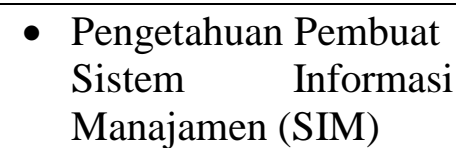 \\
\hline & & $\begin{array}{ll}\text { - } & \text { Kemampuan Pembuat } \\
\text { Sistem Informasi } \\
\text { Manajamen (SIM) } \\
\end{array}$ \\
\hline & & - Manfaat \\
\hline & \multirow[t]{3}{*}{$\begin{array}{l}\text { 2. Perangkat Keras } \\
\text { (Hardware) }\end{array}$} & $\begin{array}{ll}\text { - } & \text { Kesulitan } \\
\text { Pengoperasian } \\
\text { Perangkat }\end{array}$ \\
\hline & & - Kualitas Perangkat \\
\hline & & - Kebutuhan Perangkat \\
\hline & \multirow{3}{*}{$\begin{array}{l}\text { 3. Perangkat Lunak } \\
\text { (SoftWare) }\end{array}$} & - Mudah digunakan \\
\hline & & - Kelengkapan Menu \\
\hline & & $\begin{array}{l}\text { - Frekuensi terjadinya } \\
\text { kesalahan atau error }\end{array}$ \\
\hline & \multirow[t]{4}{*}{ 4. Data } & $\begin{array}{ll}\text { - Kemudahan } \\
\text { mendapatkan data }\end{array}$ \\
\hline & & $\begin{array}{ll}\text { - Kelengkapan } \\
\text { yang digunakan }\end{array}$ \\
\hline & & $\begin{array}{l}\text { - Kebenaran data yang } \\
\text { digunakan }\end{array}$ \\
\hline & & $\begin{array}{l}\text { - Kemudahan } \\
\text { menginput data }\end{array}$ \\
\hline & \multirow[t]{2}{*}{ 5. Jaringan } & - Kecepatan akses \\
\hline & & - Kemudahan akses \\
\hline
\end{tabular}


Tabel 3.2

Instrumen Pengukuran Variabel Y (Kualitas Pelayanan)

\begin{tabular}{|c|c|c|}
\hline Variabel & Indikator & Ukuran \\
\hline \multirow{6}{*}{$\begin{array}{l}\text { Kualitas } \\
\text { Pelayanan(Y) } \\
\text { Menurut } \\
\text { Fitzsimmons } \\
\text { dalam } \\
\text { Sedarmayanti } \\
(2009: 253-254)\end{array}$} & \multirow[t]{2}{*}{ Bukti fisik(Tangibles) } & $\begin{array}{l}\text { - Penampilan karyawan } \\
\text { rapih dan Sopan }\end{array}$ \\
\hline & & - Kelengkapan Fasilitas \\
\hline & Empati(Empathy) & $\begin{array}{l}\text { - Sikap ramah } \\
\text { - Murah senyum } \\
\text { - Menyapa Pelanggan } \\
\text { - Perhatian karyawan }\end{array}$ \\
\hline & $\begin{array}{l}\text { Daya Tanggap } \\
\text { (Responsivines) }\end{array}$ & $\begin{array}{l}\text { - Kecepatan Daya } \\
\text { Tanggap }\end{array}$ \\
\hline & Kehandalan (Reliability) & - Kemampuan karyawan \\
\hline & Jaminan(Assurance) & $\begin{array}{l}\text { - Jaminan keamanan } \\
\text { dan keselamatan }\end{array}$ \\
\hline
\end{tabular}

Tabel 3.3

Instrumen penelitian dalam Skala Likert

\begin{tabular}{|c|c|c|}
\hline $\begin{array}{c}\text { Instrumen } \\
\text { Skala Likert }\end{array}$ & Skala & Skor \\
\hline 1 & Sangat Setuju (SS) & 5 \\
\hline 2 & Setuju (S) & 4 \\
\hline 3 & Ragu-ragu (RG) & 3 \\
\hline 4 & Kurang Setuju (KS) & 2 \\
\hline 5 & Tidak Setuju (TS) & 1 \\
\hline
\end{tabular}

Sumber : Sugiyono (2016)

Tabel 3.4

Klasifikasi Koefisien reliabilitas

\begin{tabular}{|c|l|}
\hline Nilai & Keterangan \\
\hline $\mathrm{r}_{11}<0,20$ & Sangat Rendah \\
$0,20 \leq \mathrm{r}_{11}<0,40$ & Rendah \\
$0,40 \leq \mathrm{r}_{11}<0,70$ & Sedang \\
$0,70 \leq \mathrm{r}_{11}<0,90$ & Tinggi \\
$0,90 \leq \mathrm{r}_{11}<1,00$ & Sangat Tinggi \\
\hline
\end{tabular}


Tabel 3.5

Interprestasi Kolerasi Sederhana

\begin{tabular}{|c|c|}
\hline $0,00-1,99$ & Sangat Rendah \\
\hline $0,20-0,399$ & Rendah \\
\hline $0,40-0,599$ & Sedang \\
\hline $0,60-0,799$ & Kuat \\
\hline $0,80-1,000$ & Sangat Kuat \\
\hline
\end{tabular}

Sumber: Sugiyono, 2016

Tabel 5.1

Karakteristik Responden Berdasarkan Jenis Kelamin

\begin{tabular}{|c|c|c|c|}
\hline No & Jenis Kelamin & Jumlah(orang) & Persentase(\%) \\
\hline 1 & Laki-laki & 33 & $60 \%$ \\
\hline 2 & Perempuan & 22 & $40 \%$ \\
\hline \multicolumn{2}{|c|}{ Total } & 55 & $100 \%$ \\
\hline
\end{tabular}

Sumber: Hasil Penelitian, 2019

Tabel 5.2

Karakteristik Responden Berdasarkan Usia

\begin{tabular}{|c|c|c|c|}
\hline No & Usia(Tahun) & Jumlah(orang) & Persentase(\%) \\
\hline 1 & 25 & 1 & $1,81 \%$ \\
\hline 2 & $>25-30$ & 17 & $30,90 \%$ \\
\hline 3 & $>30-35$ & 6 & $10,90 \%$ \\
\hline 4 & $>35-40$ & 5 & $9,09 \%$ \\
\hline 5 & $>40$ tahun & 26 & $47,27 \%$ \\
\hline \multicolumn{2}{|c|}{ Jumlah } & 55 & $100 \%$ \\
\hline
\end{tabular}

Sumber: Hasil Penelitian, 2019

Tabel 5.3

Karakteristik Responden Berdasarkan Tingkat Pendidikan

\begin{tabular}{|c|c|c|c|}
\hline No & Pendidikan & Jumlah(orang) & Persentase(\%) \\
\hline 1 & SLTA Sederajat & 20 & $36,36 \%$ \\
\hline 2 & S1 (Sarjana) & 33 & $60 \%$ \\
\hline
\end{tabular}




\begin{tabular}{|c|c|c|c|}
\hline 3 & S2 (Magister) & 2 & $3,64 \%$ \\
\hline \multirow{2}{*}{ Jumlah } & 55 & $100 \%$ \\
\hline
\end{tabular}

Sumber: Hasil Penelitian, 2019

Tabel 5.4

Karakteristik Responden Berdasarkan Pekerjaan

\begin{tabular}{|c|c|c|c|}
\hline No & Pekerjaan & Jumlah(orang) & Persentase(\%) \\
\hline 1 & Wiraswasta & 12 & $21,83 \%$ \\
\hline 2 & Pegawai Swasta & 35 & $63,63 \%$ \\
\hline 3 & Lainnya & 8 & $14,45 \%$ \\
\hline \multicolumn{2}{|c|}{ Jumlah } & 55 & $100 \%$ \\
\hline
\end{tabular}

Sumber: Hasil Penelitian, 2019

Tabel 5.11

Setiap pekerjaan/tugas selalu membutuhkan teknologi komputer.

\begin{tabular}{|c|c|c|c|}
\hline No & Alternatif Jawaban & Frekuensi & Persentase(\%) \\
\hline 1 & Sangat Setuju (5) & 14 & $25.45 \%$ \\
\hline 2 & Setuju (4) & 25 & $45.45 \%$ \\
\hline 3 & Ragu-ragu (3) & 9 & $16.4 \%$ \\
\hline 4 & Kurang Setuju (2) & 7 & $12.7 \%$ \\
\hline 5 & Sangat Tidak Setuju (1) & 0 & $0 \%$ \\
\hline \multicolumn{2}{r}{ Jumlah } & 55 & $100 \%$ \\
\hline
\end{tabular}

Sumber: Hasil Penelitian, 2019

Tabel 5.20

Pemanfaatan teknologi informasi memudahkan pegawai dalam memberikan informasi yang tersedia

\begin{tabular}{|c|c|c|c|}
\hline No & Alternatif Jawaban & Frekuensi & Persentase $(\%)$ \\
\hline 1 & Sangat Setuju (5) & 18 & $32,7 \%$ \\
\hline 2 & Setuju (4) & 36 & $65,5 \%$ \\
\hline 3 & Ragu-ragu (3) & 1 & $1,8 \%$ \\
\hline 4 & Kurang Setuju (2) & 0 & $0 \%$ \\
\hline 5 & Sangat Tidak Setuju (1) & 0 & $0 \%$ \\
\hline \multicolumn{2}{|r|}{ Jumlah } & 55 & $100 \%$ \\
\hline
\end{tabular}

Sumber: Hasil Penelitian, 2019 
Tabel 5.33

Kemudahan dihubungi melalui telepon terlihat sudah baik.

\begin{tabular}{|c|c|c|c|}
\hline No & Alternatif Jawaban & Frekuensi & Persentase $(\%)$ \\
\hline 1 & Sangat Setuju (5) & 11 & $20 \%$ \\
\hline 2 & Setuju (4) & 29 & $52,7 \%$ \\
\hline 3 & Ragu-ragu (3) & 14 & $25,5 \%$ \\
\hline 4 & Kurang Setuju (2) & 1 & $1,8 \%$ \\
\hline 5 & Sangat Tidak Setuju (1) & 0 & $0 \%$ \\
\hline & Jumlah & 55 & $100 \%$ \\
\hline
\end{tabular}

Sumber: Hasil Penelitian, 2019

Tabel 5.40

Ketelitian karyawan saat melayani nasabah terlihat sudah baik.

\begin{tabular}{|c|c|c|c|}
\hline No & Alternatif Jawaban & Frekuensi & Persentase(\%) \\
\hline 1 & Sangat Setuju (5) & 20 & $36,4 \%$ \\
\hline 2 & Setuju (4) & 35 & $63,6 \%$ \\
\hline 3 & Ragu-ragu (3) & 0 & $0 \%$ \\
\hline 4 & Kurang Setuju (2) & 0 & $0 \%$ \\
\hline 5 & Sangat Tidak Setuju (1) & 0 & $0 \%$ \\
\hline & Jumlah & 55 & $100 \%$ \\
\hline
\end{tabular}

Sumber: Hasil Penelitian, 2019 
Tabel 5.42

Uji Validitas Variabel Sistem Informasi Manajemen (X)

\begin{tabular}{|c|c|c|c|}
\hline \multirow{2}{*}{ Pernyataan } & $\begin{array}{c}\text { Corrected Item } \\
\text { Total } \\
\text { Correlation }\end{array}$ & \multirow{2}{*}{$\mathrm{r}_{\text {tabel }}$} & Validitas \\
\cline { 2 - 3 } & $\left.\mathrm{r}_{\text {hitung }}\right)$ & & \\
\hline X1 & 0,611 & 0,266 & Valid \\
\hline X2 & 0,455 & 0,266 & Valid \\
\hline X3 & 0,616 & 0,266 & Valid \\
\hline X4 & 0,479 & 0,266 & Valid \\
\hline X5 & 0,325 & 0,266 & Valid \\
\hline X6 & 0,494 & 0,266 & Valid \\
\hline X7 & 0,342 & 0,266 & Valid \\
\hline X8 & 0,504 & 0,266 & Valid \\
\hline X9 & 0,323 & 0,266 & Valid \\
\hline X10 & 0,565 & 0,266 & Valid \\
\hline X11 & 0,462 & 0,266 & Valid \\
\hline X12 & 0,459 & 0,266 & Valid \\
\hline X13 & 0,541 & 0,266 & Valid \\
\hline X14 & 0,531 & 0,266 & Valid \\
\hline X15 & 0,533 & 0,266 & Valid \\
\hline
\end{tabular}

Sumber: Hasil Penelitian, 2019 
Tabel 5.43

Uji Validitas Variabel Kualitas Pelayanan (Y)

\begin{tabular}{|c|c|c|c|}
\hline Pernyataan & $\begin{array}{c}\text { Corrected Item } \\
\text { Total } \\
\text { Correlation }\end{array}$ & $r_{\text {tabel }}$ & Validitas \\
\hline & $\left(\mathrm{r}_{\text {hitung }}\right)$ & & \\
\hline Y1 & 0,532 & 0,266 & Valid \\
\hline $\mathrm{Y} 2$ & 0,616 & 0,266 & Valid \\
\hline Y3 & 0,542 & 0,266 & Valid \\
\hline Y4 & 0,512 & 0,266 & Valid \\
\hline Y5 & 0,553 & 0,266 & Valid \\
\hline Y6 & 0,380 & 0,266 & Valid \\
\hline Y7 & 0,212 & 0,266 & Tidak Valid \\
\hline Y8 & 0,421 & 0,266 & Valid \\
\hline Y9 & 0,447 & 0,266 & Valid \\
\hline Y10 & 0,329 & 0,266 & Valid \\
\hline Y11 & 0,371 & 0,266 & Valid \\
\hline Y12 & 0,450 & 0,266 & Valid \\
\hline Y13 & 0,369 & 0,266 & Valid \\
\hline Y14 & 0,728 & 0,266 & Valid \\
\hline Y15 & 0,627 & 0,266 & Valid \\
\hline Y16 & 0,569 & 0,266 & Valid \\
\hline Y17 & 0,696 & 0,266 & Valid \\
\hline Y18 & 0,378 & 0,266 & Valid \\
\hline Y19 & 0,651 & 0,266 & Valid \\
\hline Y20 & 0,550 & 0,266 & Valid \\
\hline Y21 & 0,317 & 0,266 & Valid \\
\hline Y22 & 0,579 & 0,266 & Valid \\
\hline
\end{tabular}

Sumber: Hasil Penelitian, 2019 
Tabel 5.44

Uji Reliabilitas Variabel Sistem Informasi Manajemen (X)

Reliability Statistics

\begin{tabular}{|r|r|}
\hline Cronbach's Alpha & N of Items \\
\hline .769 & 15 \\
\hline
\end{tabular}

Sumber: Hasil Output SPSS .20

Tabel 5.45

Uji Reliabilitas Variabel Kualitas Pelayanan (Y)

Reliability Statistics

\begin{tabular}{|r|r|}
\hline $\begin{array}{l}\text { Cronbach's } \\
\text { Alpha }\end{array}$ & N of Items \\
\hline .859 & 21 \\
\hline
\end{tabular}

Sumber: Hasil Output SPSS .2019

Tabel 5.47

Interprestasi Koefisien

Korelasi

\begin{tabular}{|c|c|}
\hline $0,00-1,99$ & Sangat Rendah \\
\hline $0,20-0,399$ & Rendah \\
\hline $0,40-0,599$ & Sedang \\
\hline $0,60-0,799$ & Kuat \\
\hline $0,80-1,000$ & Sangat Kuat \\
\hline
\end{tabular}

Sumber :Sugiyono, 2016 
Tabel 5.49

Hasil Analisis Regresi Linier Sederhana

\begin{tabular}{|c|r|r|c|c|c|}
\hline Model & $\begin{array}{c}\text { Unstandardized } \\
\text { Coefficients }\end{array}$ & $\begin{array}{c}\text { Standardized } \\
\text { Coefficients }\end{array}$ & $\mathrm{t}$ & Sig. \\
\cline { 2 - 6 } & $\mathrm{B}$ & $\begin{array}{c}\text { Std. } \\
\text { Error }\end{array}$ & Beta & & \\
\hline $\begin{array}{c}\text { (Const } \\
\text { ant) } \\
\text { SIM }\end{array}$ & 55.484 & 11.399 & & 4.868 & .000 \\
\hline
\end{tabular}

a. Dependent Variable: KUALITAS PELAYANAN

Sumber: Hasil Output SPSS .20

Tabel

5.50

\section{Hasil Uji}

$\mathbf{T}$

Coefficients $^{\mathrm{a}}$

\begin{tabular}{|c|c|c|c|c|c|}
\hline \multirow[t]{2}{*}{ Model } & \multicolumn{2}{|c|}{$\begin{array}{c}\text { Unstandardized } \\
\text { Coefficients }\end{array}$} & $\begin{array}{l}\text { Standardized } \\
\text { Coefficients }\end{array}$ & $t$ & Sig. \\
\hline & B & $\begin{array}{l}\text { Std. } \\
\text { Error }\end{array}$ & Beta & & \\
\hline $1^{\text {(Constant) }}$ & 55.484 & $\begin{array}{r}11.39 \\
9\end{array}$ & & 4.868 & .000 \\
\hline SIM & .493 & .177 & .357 & 2.783 & .007 \\
\hline
\end{tabular}

a. Dependent Variable: KUALITAS PELAYANAN

Sumber: Hasil Output SPSS .20 